\title{
CARTAS DE ERASMO AO IMPERADOR SOBRE A EMANCIPAÇÃO: JOSÉ DE ALENCAR E O CULTIVO DA DEPENDÊNCIA ENTRE SENHORES E ESCRAVIZADOS
}

\author{
Cristina Ferreira
}

\begin{abstract}
Resumo: Entre 1867-68, circulou no universo letrado brasileiro, a terceira série das Cartas de Erasmo, com três missivas "Sobre a Emancipação", destinadas ao Imperador D. Pedro II. O artigo procura examinar em detalhes os sentidos das narrativas literárias das Cartas de Erasmo ao Imperador sobre a Emancipação, explorando com mais especificidade as polêmicas entre a legislação sobre a escravidão e a imigração estrangeira para o Brasil. O escritor apontava como única proposta possível de transição entre a escravidão e a liberdade, o cultivo das relações de dependência entre senhores e escravizados, operadas por meio da mudança nos costumes e na índole da sociedade, em um processo que "adoçava" o cativeiro, transformado em servidão até chegar à ausência de amparo dos escravocratas, que resultaria na redução do domínio senhorial e, paulatinamente, assumiria a forma de "tutela benéfica" dos escravos e libertos.
\end{abstract}

Palavras-chave: Cartas de Erasmo. Emancipação dos escravos. José de Alencar.

\section{ERASMUS LETTERS TO THE EMPEROR ON THE EMANCIPATION: JOSÉ DE ALENCAR AND THE CULTIVATION OF DEPENDENCE}

\begin{abstract}
Between 1867-68, the third series of the Letters of Erasmo circulated in the Brazilian literate universe, with three missives "Sobre a Emancipação", aimed at Emperor D. Pedro II. The article seeks to examine in detail the meanings of the literary narratives of the Letters of Esmo to the Emperor on Emancipation, exploring more specifically the controversies between legislation on slavery and foreign immigration to Brazil. The writer pointed out as the only possible proposal for the transition between slavery and freedom, the cultivation of dependency relations between masters and enslaved people, operated by changing the customs and nature of society, in a process that "sweetened" captivity, transformed into servitude until the absence of support from the slave-owners, which would result in the reduction of the mastery of the land and, gradually, it would take the form of "beneficial tutelage" for the slaves and freedmen.
\end{abstract}

Keywords: The Erasmus Letters. Emancipation of slaves. José de Alencar.

\section{CARTAS DE ERASMO AL EMPERADOR SOBRE LA EMANCIPACIÓN: EL CULTIVO DE LA DEPENDENCIA ENTRE MAESTROS Y ESCLAVITUDES}

Resumen: Entre 1867-68, circula en el universo alfabetizado brasileño la tercera serie de las Cartas de Erasmo, con tres misivas "Sobre la Emancipación", destinadas al Emperador D. Pedro II. El artículo busca examinar en detalle los significados de las narrativas literarias de las Cartas de Erasmo al Emperador sobre la Emancipación, explorando con más especificidad las controversias entre la legislación sobre esclavitud y la inmigración extranjera a Brasil. El escritor señaló como única propuesta posible para la transición entre la esclavitud y la libertad, el cultivo de relaciones de dependencia entre amos y esclavizados, operadas a través de cambios en las costumbres y naturaleza de la sociedad, en un proceso que "endulzó" el cautiverio, transformado en servidumbre, hasta llegar a la ausencia del apoyo de los esclavos, lo que se traduciría en la reducción del dominio sobre la tierra y, gradualmente, tomaría la forma de "tutela benéfica" para los esclavos y libertos.

Palabras clave: Cartas de Erasmo. Emancipación de esclavos. José de Alencar.

\footnotetext{
${ }^{1}$ Doutora em História Social pela Universidade Estadual de Campinas - Unicamp (2015); Mestre em História do Brasil pela Universidade Federal de Santa Catarina (1998) e graduada em História pela Fundação Universidade Regional de Blumenau (1992). Professora efetiva da Universidade Regional de Blumenau - FURB, nas disciplinas História do Brasil II e III; Prática de Pesquisa Histórica I e II, Projeto de Pesquisa em História e Trabalho de Conclusão de Curso.
}

Revista Escritas do Tempo - v. 3, n. 8, mai-ago/ 2021 - p. 09-29 
O crescente interesse manifesto por historiadores em relação à produção de textos evidencia o reconhecimento da importância em construir afinidades e entrelaces com o real, de modo a inscrever, em seu âmago, indícios verossímeis e expressões parciais das razões e dos sentimentos partilhados pelos escritores e seus contemporâneos. A narrativa literária era considerada pelos homens de letras oitocentistas como importante via de instrução e condicionamento moral.

Os literatos construíram vínculos expressivos entre o romance histórico, a história erudita e os monumentos públicos, responsáveis por narrar a trajetória da organização do Brasil e singularizar o país. Tais produções articulavam imagens de diferentes tempos históricos, demarcando que para a literatura, "os passados são sempre de alguma forma presentes, ainda vivos, nos quais as novas criações se inspiram" (CHARTIER, 2020, p. 36).

Mediante a aproximação da "operação historiográfica" com a narrativa, proliferam as discussões em torno dos elementos de realidade e ficção dos textos. Da simbiose entre História e outros gêneros literários, as narrativas que circularam no mundo letrado oitocentista forneceram uma imensidão de substratos para a investigação histórica, com pistas fragmentárias de suas redes de interlocução social e intertextual.

Nascido no ano de 1829 no Ceará, Alencar era filho do Senador de quem herdou seu nome e Ana Josefina de Alencar. Bacharel em Direito pela Faculdade de São Paulo (1849), envolveu-se na política em 1861, quando foi eleito Deputado Geral no Ceará (Partido Conservador). Em sua autobiografia intitulada Como e porque sou romancista, reconheceu que o único "novo homem e quase estranho" que nasceu foi o político, universo considerado "uma religião" pela sua família (ALENCAR, 1893, p. 34), chegando a ocupar uma posição de destaque no exercício do cargo de Ministro da Justiça entre 1868 e $1870^{2}$.

\footnotetext{
${ }^{2}$ Em 1869 surgiram duas vagas ao Senado pelo Ceará e, na oportunidade, Alencar atendia ao critério de idade mínima de 40 anos para efetivação da candidatura, considerada natural e legítima, visto que tinha ocupado o cargo de deputado geral cearense por duas legislaturas, era "filho do Ceará" e teria a oportunidade de honrar a memória de seu pai, que também havia exercido o cargo. Contudo, essa decisão não foi corroborada pelo Imperador que, a despeito dos frequentes exemplos de ministros candidatos à senatoria, havia considerado incompatível a candidatura de Alencar. Diante de tal argumentação, Alencar propôs deixar o governo, caso houvesse alguma "incompatibilidade moral entre essa candidatura e a posição de ministro" (ALENCAR, 1977, p. 70). Ao findar o processo eleitoral, Alencar foi o candidato mais votado, com 1.185 sufrágios. Ainda que vitorioso, a indicação para o cargo somente era efetivada a partir da decisão do Imperador, que optou por não referendar seu nome como senador, atitude pouco usual, porque era costume a indicação do candidato com maior votação (CARVALHO, 2008, p. 79). Obviamente essa atitude do Imperador interferiu nas relações entre ambos, que já não eram adocicadas desde as críticas tecidas ao governo imperial por José de Alencar na publicação das Cartas de Erasmo.
} 
Como homem de letras, José de Alencar foi um dos representantes do romantismo literário brasileiro, ao lado de Gonçalves Dias, Álvares de Azevedo e Joaquim Manuel de Macedo, com romances e peças de teatro cujas temáticas abarcavam desde o Brasil colonial até a vida urbana e interiorana do século XIX. Foi o caso do romance Til, inicialmente publicado em folhetim no jornal A República (1871), cuja narrativa era pautada na vida do interior de São Paulo. Entre setembro de 1854 e julho de 1855, José de Alencar publicou o folhetim Ao correr da pena, no jornal Correio Mercantil, com artigos que versavam sobre o teatro, questões sociais e debates políticos envolvendo a Câmara e o Senado, contribuindo sensivelmente para o aumento das vendas desse periódico (MOLINA, 2015).

Ainda em outubro de 1855, assumiu o cargo de redator do Diário do Rio de Janeiro e, entre junho e agosto de 1856, publicou oito cartas abertas nesse mesmo periódico, sob o título Cartas sobre a Confederação dos Tamoios, a partir da polêmica travada com Domingos José de Magalhães sobre os Tamoios e seus conflitos com os portugueses no século XVI (FERREIRA; LENZ, 2019). A incursão que marcou definitivamente a entrada de Alencar nos círculos letrados ocorreu um ano depois, com a publicação do romance $O$ Guarani (1857), em formato de folhetim, caracterizado pelo enaltecimento dos elementos nacionais brasileiros, causando impacto diante das costumeiras práticas de leitura, concentradas nos folhetins estrangeiros traduzidos para a língua portuguesa, diante de seu peculiar caráter nacionalista.

Também publicou cartas abertas sob a denominação Cartas de Erasmo, compostas por três conjuntos de correspondências (ALENCAR, 1865, 1866a, 1866b, 1866c, 1867-1868): 1) ao Imperador D. Pedro II, destinatário principal em duas séries; 2) ao povo brasileiro; e 3) Duas cartas avulsas remetidas ao Marquês de Olinda e ao Visconde de Itaboraí. O primeiro conjunto citado compõe o corpus documental privilegiado dessa pesquisa histórica e sua relevância incide sobre o objetivo do artigo que ora se apresenta, voltado a examinar os sentidos políticos das narrativas do romancista José de Alencar nas Cartas de Erasmo sobre a emancipação dos escravizados. Sua escrita foi elaborada no formato de cartas abertas, tipologia epistolar utilizada com certa assiduidade no cenário político do Segundo Reinado (CARVALHO, 2009, p. IX-X). Tais correspondências apresentavam um forte caráter de denúncia em relação a comportamentos, instituições ou indivíduos e se manifestavam favoráveis à propagação e defesa de causas específicas. 
Ao assumirem a forma pública, costumavam atingir um "público mais amplo, que devia conhecer e se convencer das ideias dos autores" (GOMES, 2009, p. 43). Não por acaso, as críticas de Erasmo retratavam uma espécie de radiografia da crise vivida pelo Império (RODRIGUES, 2001, p. 63) e, simultaneamente, cumpriam uma função de instrução pública, sobretudo por conta das temáticas vinculadas à política ${ }^{3}$. Sua proposta era admoestar seus destinatários sobre diversos temas da arena política do Segundo Reinado (1840-1889), como a Guerra do Paraguai, finanças nacionais, a organização política e econômica, o sistema eleitoral e a emancipação dos escravos.

A primeira série, intitulada Ao Imperador, Cartas de Erasmo foi publicada às quintas-feiras pela Typografia de Mello, em novembro de 1865 e era composta por dez missivas, com aproximadamente oito páginas, vendidas nas principais livrarias (ALENCAR, 1865). Seu conteúdo narrativo consistia em um apelo ao Monarca para intervir e livrar o Brasil da crise política (CARVALHO, 2009, p. XIX), temática recorrente também na imprensa, diante das reformas políticas e sociais que estavam em voga nesse período. O texto era pautado no aconselhamento do Imperador para a preservação da inviolabilidade das atribuições imperiais e entusiasmada defesa do Poder Moderador, em reconhecimento ao Quarto Poder, considerado por Alencar como "a mais alta expressão da majestade" (ALENCAR, 1865, p. 57).

Em 1866, escreveu a segunda série, intitulada Ao Povo: Cartas Políticas de Erasmo, constituída por nove cartas predominantemente ligadas à Guerra do Paraguai (ALENCAR, 1866b, p. 72). Havia uma crise econômica advinda do conflito, responsável por consumir uma quantidade imensa de recursos, além das vidas e do sangue derramado diante do que José de Alencar considerava como "imperícia dos generais mercenários enviados pelo governo para limitar-se ao comando dos soldados pelo preço de milhões" (ALENCAR, 1866b, p. 4).

Articulada a essa questão, nos debates da cultura letrada, predominava o tema da emancipação dos escravos, alvo da terceira série de cartas, denominada Ao Imperador: Novas Cartas Políticas de Erasmo e publicada em 1867-68. A complexidade dessa questão foi amplamente discutida pela historiografia brasileira (CHALHOUB, 2012a; MAMIGONIAN, 2014; SCHWARCZ; GOMES, 2018), com destaque para uma abordagem que aponta a predominância dos costumes escravocratas, responsáveis pelas

\footnotetext{
3 Alencar assemelhava seu propósito ao de Erasmo, pois procurava instruir o Imperador na maneira correta de governar, além de aconselhar também a nação e políticos. Mais detalhes em: (Cf.: CARVALHO, 2009; PARRON, 2008; ERASMO, 1998).
} 
mais variadas formas de ações contrárias às leis imperiais e muito longe de representar rupturas reais no sistema escravista, demarcando a contradição entre a ordem pública e o "direito" privado de possuir e adquirir escravos.

Sem autoria declarada, as cartas eram assinadas com o pseudônimo Erasmo, escolha aparentemente relacionada ao livro A Educação de um Príncipe Cristão, de Erasmo de Roterdã, escrito em 1516, três anos após Nicolau Maquiavel ter composto $O$ Príncipe. Ambos elaboraram seus tratados versando sobre a melhor forma de preparar o governante para ser eficiente na gestão, reagindo ao período de instabilidade política da época e ao pânico moral, provocado por um período de aspirações dinásticas e ambições territoriais (ERASMO, 1998, p. 271) por parte de famílias europeias poderosas.

Não foi à toa a escolha desse codinome, que remetia aos escritos de Erasmo de Roterdã, como uma "espécie de metonímia dos specula principis (espelho do príncipe)" (PARRON, 2008, p. 16-17). Também é plausível dizer que José de Alencar se reconhecia como um apóstolo salvador da dignidade da razão humana em meio à contaminação das formas de vida pública, circunstância que justificava a escrita das Cartas e indicava seus princípios de entendimento da sociedade em que vivia como viciada em corrupção (ALENCAR, 1865, p. 3).

Nas Cartas de Erasmo ficaram nítidas as concepções políticas e letradas de José de Alencar, representante do romantismo literário brasileiro, ao lado de Gonçalves Dias, Álvares de Azevedo e Joaquim Manuel de Macedo, com romances e peças de teatro cujas temáticas abarcavam desde o Brasil colonial até a vida urbana e interiorana do século XIX. Seu ingresso no mundo literário oitocentista ocorreu por meio da publicação do folhetim intitulado Cinco Minutos, no final de 1856, nas páginas do jornal Diário do Rio de Janeiro, onde exerceu o cargo de redator-chefe. Esse periódico, ao lado do Jornal do Commercio e do Correio Mercantil, figurava como um dos três jornais políticos mais importantes do Rio de Janeiro (MOLINA, 2015, p. 225), indicativo de sua relevância cultural no universo letrado nacional.

Alencar apontava que sua família considerava a política como uma religião (ALENCAR, 1893, p. 34) e, não por acaso, pautou sua carreira na área, seja como Deputado Geral no Ceará, pelo Partido Conservador ou até mesmo no exercício do cargo de Ministro da Justiça (1868 a 1870), pelo Gabinete 16 de Julho, que tinha por tarefa barrar a discussão da emancipação dos escravos (CHALHOUB, 2003, p. 192). Também concorreu ao senado (1869) pelo Ceará e foi o candidato mais votado, com 1.185 sufrágios (MENEZES, 1965, p. 280). Ainda que vitorioso, a indicação somente 
seria efetivada a partir da decisão do Imperador, que optou por não referendar seu nome ao cargo de senador. Essa era uma atitude pouco usual, pois o costume previa a indicação do candidato com maior votação, embora o monarca tenha nomeado o segundo e o quinto colocado.

Obviamente essa decisão do Imperador interferiu nas relações entre ambos, que já não eram adocicadas desde as críticas tecidas ao governo imperial na publicação das Cartas de Erasmo (1865-1868). Com vigor e insistência, seu posicionamento marcante transparecia claramente e, entre as cartas iniciais (1865) e as últimas epístolas, o caráter amistoso de aconselhamento cedeu espaço a um tom mais agressivo, que reportava ao Imperador uma ação de favorecimento a outras nações, acusando-o de "favonear, mesmo contra o Brasil, as paixões estrangeiras” (ALENCAR, 1867-1868, p. 9).

Ao direcionar três missivas sobre a emancipação na série Ao Imperador: Novas Cartas Políticas de Erasmo ${ }^{4}$, Alencar apontava a participação do Monarca e seu incentivo na questão, sendo considerado a figura principal que empurrava o governo nessa direção. Contudo, sustentava que a escravidão deveria ser tratada como um fato social pertencente às instituições dos povos, contrariando a opinião imperial, ao propor que a reforma não se efetivasse "pela arrogância de teorias" e por medidas legislativas (ALENCAR, 1867-1868, p. 13-14).

Além disso, reafirmava que o direito e a moral eram relativos às circunstâncias e obrigatoriamente deveriam respeitar as peculiaridades de cada situação, com indicações sobre os efeitos prejudiciais que o encaminhamento legal traria sobre a emancipação. Essa formulação foi tomada por uma vertente historiográfica que simplesmente compreendia as Cartas de Erasmo como defensoras da continuidade da escravidão no Brasil (PARRON, 2008, p. 9), conferindo o título de escravocrata para José de Alencar. Todavia, essa forma de análise foi contraposta por José Murilo de Carvalho, que considerou impossível encontrar nas Cartas de Erasmo "qualquer defesa da justiça e da moralidade da escravidão em si” (CARVALHO, 2009, p. XXVII).

Sem a pretensão de discordar dos rumos da historiografia referenciada, muito menos discutir se José de Alencar era ou não escravocrata, as questões centrais desse texto concentram-se na atenção aos detalhes e pormenores das cartas Sobre a

\footnotetext{
${ }^{4}$ Sua configuração interna ficou assim estabelecida nessa última série: 1) Sem atribuição temática especificada, primeira (24/06/1867) e sétima (15/03/1868); 2) Sobre a Emancipação, segunda $(15 / 07 / 1867)$, terceira (20/07/1867) e quarta (26/07/1867); 3) Sobre o Donativo Imperial, quinta $(20 / 09 / 1867)$; 4) Sobre a Guerra, sexta carta $(23 / 09 / 2867)$.
} 
Emancipação, como um traço distintivo no estudo da literatura como fonte de pesquisa nos debates políticos e intelectuais acerca da escravidão entre 1865 e 1871 .

A discussão acerca da substituição da mão de obra escrava tornou-se pauta com maior nitidez a partir de 1850 , por conta da pressão internacional para o fim da escravidão brasileira, viabilizada tanto pela Inglaterra quanto pela França. Por outro lado, Erasmo argumentava que enquanto as mais poderosas nações da Europa estavam consolidadas e com a escravidão devidamente extinta, o Brasil ainda permanecia no "limbo do desconhecido" (ALENCAR, 1867-1868, p. 38), o que justificava a demora no encaminhamento da reforma, circunstância que não trazia desonra ao país, demonstrando assim a necessidade de considerar a particularidade local. Essa concepção convergia com as proposições do liberalismo preconizadas pelo filósofo e político britânico Edmund Burke, que receberam adesão de boa parte dos políticos conservadores brasileiros, cujo argumento consistia na defesa do respeito às diferenças entre o Brasil e a Europa, a partir do tempo e das particularidades de cada um.

Diante da resposta do Império à Junta Francesa de Emancipação (1867), colocando a abolição como uma questão de "forma e oportunidade", empenhando uma garantia de que após o término da guerra com o Paraguai essa seria uma questão prioritária, Alencar sentiu-se motivado a escrever a última série das Cartas de Erasmo. Sua narrativa insistia em destacar os numerosos "cortejos" realizados pela coroa à opinião europeia, com o intuito de incluir na pauta parlamentar a discussão sobre a emancipação como “questão máxima do dia” (ALENCAR, 1867-1868, p. 12). Logo, considerava ilegítima a interferência estrangeira, incapaz de levar em conta o aspecto temporal inicial da construção do estado nacional brasileiro e discordava da intromissão de outros países nessa questão, apontando que seus discursos em favor da libertação dos escravos no Brasil não tinham legitimidade.

Tal cenário político motivou José de Alencar a acusar o Imperador de ter adquirido foros de um "rei filantropo", em alusão à concessão de liberdade aos escravos do Império, à congratulação com um "mimo especial" aos superiores de ordens religiosas que tenham emancipado o ventre, bem como ao estímulo às alforrias por meio de "mercês honoríficas" (ALENCAR, 1867-1868, p. 12-13). Por extensão, criticava essa política imperial e apontava seus defensores como dotados de "espíritos mesquinhos e retrógados", característica considerada "terrível" em se tratando de uma reforma. Isso quer dizer que reprovava a filantropia por considerá-la responsável por imputar impopularidade à escravidão, ainda mais que se tratava de um "fato social" 
ainda em voga, defendendo que somente teria seu fim decretado, quando caísse em desuso (ALENCAR, 1867-1868, p. 14).

A filantropia imperial era reconhecida por Alencar como a manifestação do ponto de vista exclusivo de D. Pedro II acerca do tema da emancipação, chegando a afirmar que, ao invés de "impulsos generosos", essa atitude do Imperador deveria ser tratada como uma "conspiração do mal" e uma "terrível impiedade" (ALENCAR, 18671868, p. 13). Além disso, atribuía o interesse do monarca em relação aos debates emancipacionistas, ao fato de que o Brasil era o "único país onde a escravidão existia", circunstância que comovia a população e a envergonhava, pois ela não aceitava figurar "na última fila das nações cultas" por causa da escravidão (ALENCAR, 1867-1868, p. 37-38).

Alencar tentava demonstrar que tanto a Inglaterra quanto a França, considerados os maiores incentivadores da emancipação no Brasil, não possuíam autonomia para condenar a escravidão em território brasileiro. Sua justificativa era pautada no fato de que a Inglaterra renunciara ao tráfico de africanos com pesar, diante do receio de que essa atividade "caísse nas mãos de outra nação", enquanto a França extinguira a escravidão em fins do século XVIII para retomá-la e aboli-la apenas em 1848.

Por isso, defendia com unhas e dentes que nenhum dos dois países poderia condenar o Brasil, pautado na justificativa de que na Europa predominava o pauperismo na última classe da sociedade, circunstância que rebaixava a humanidade "mais do que à antiga escravidão", em alusão à proletarização que resultou em condições miseráveis de vida para certas camadas da população. Seu alerta era para que o Brasil, diante das opiniões contrárias à escravidão, não se deixasse dominar pelo "pânico" (ALENCAR, 1867-1868, p. 39-40) e tomasse suas próprias decisões, em respeito às particularidades nacionais e aos costumes.

A opinião internacional e sua interferência nos assuntos brasileiros eram viabilizadas, segundo Alencar, por filantropos de gabinete que degustavam o "bom tabaco de Havana e a taça do excelente café do Brasil", enquanto redigiam protestos em favor da causa emancipacionista. Diante disso, Alencar não compreendia a atenção direcionada à propaganda filantrópica produzida em locais elegantes, por sujeitos que ignoravam a origem dos produtos consumidos, atitude julgada hipócrita pelo autor, já que esses indivíduos não conseguiriam abster-se do "gosto requintado" (ALENCAR, 1867-1868, p. 28-29) dos melhores produtos provenientes da força do trabalho escravo. 
Em se tratando de um tema tão instigante e polêmico, a imprensa incorporou com grande furor e interesse as discussões acerca do processo de emancipação dos escravos. Abolicionistas e escravocratas se digladiavam frente a uma multiplicidade de opiniões. Os defensores da libertação dos escravos condenavam o cativeiro e publicaram jornais para expressar seu descontentamento com o estado geral da sociedade e da política (AZEVEDO, 2003, p. 42). Em contrapartida, outros grupos apoiavam com veemência a continuidade do regime escravista, especialmente os grandes proprietários de terras, sob a alegação de ser a mão de obra escrava das fazendas a responsável por ter "sustentado desde o primeiro até o último cidadão" (S. PAULO, 1870, p. 2).

No âmbito da transição entre a escravidão e a liberdade, Alencar destacava a importância da História como "grande mestra", em alusão à recordação de que "os povos nossos progenitores foram também escravos e adquiriram nessa escola do trabalho e do sofrimento, a têmpera necessária para conquistar seu direito" (ALENCAR, 1867-1868, p. 22). Seu argumento era forjado na proposição de que instituições mais bárbaras do que a escravidão já existiram e, portanto, embora fosse uma forma rude do direito, também representava progresso e instrumento de civilização, com a máxima: "se a escravidão não fosse inventada, a marcha da humanidade seria impossível" (ALENCAR, 1867-1868, p. 15-18).

Imputava ao tráfico uma característica benéfica, sob a justificativa de que havia sido a atividade responsável por proporcionar aos africanos o contato com a civilização. Afirmava que embora a "raça branca" tivesse reduzido o "africano à condição de uma mercadoria, nobilitou-o não só pelo contato, como pela transformação do homem civilizado" (ALENCAR, 1867-1868, p. 22). Isso significa que, na leitura alencariana, a escravidão havia habilitado o africano à civilidade por meio do trabalho, interpretado como fundamental para instruir e moralizar aqueles que jaziam na incivilidade. $O$ cunho racista dessas afirmações se adensava nas Cartas de Erasmo à medida que alertava: caso a "civilização" penetrasse na África, não haveria, para infelicidade dos filantropos, outro meio além da escravidão para encaminhar a civilidade naquele continente (ALENCAR, 1867-1868, p. 31).

Mesmo diante de controvérsias e conflitos, as narrativas de Erasmo não eram simples dissonâncias entre a política imperial e sua opinião, afinal de contas, Alencar concordava que a escravidão estava em processo de declínio, mas não corroborava a proposta de emancipação imediata, sob a justificativa de que embora a escravidão 
estivesse se extinguindo aos poucos, "ainda não morreu; ainda se prendem a ela graves interesses de um povo" (ALENCAR, 1867-1868, p. 13). O literato acreditava nos malefícios do término abrupto do cativeiro e sustentava com veemência que "a escravidão não se extingue por ato do poder; e sim pela caducidade moral, pela revolução lenta e soturna das ideias. É preciso que seque a raiz, para faltar às ideias a seiva nutritiva". Defendia que a sustentação moral da escravidão seria naturalmente extinta e não cabia a nenhuma lei “derrogá-la” (ALENCAR, 1867-1868, p. 28; 30).

Portanto, sua proposta se aproximava da ala conservadora moderada, ao propor que o término da escravidão transcorresse como um acontecimento natural, por intermédio de uma transformação social sem intervenção direta da lei, a exemplo do modo europeu, onde foi extinta sem necessidade de uma lei precedente. Tal conjunto de propostas estava inserido nos debates políticos que levaram diversos parlamentares a sustentar a crença de que se os libertos não fossem previamente preparados para a liberdade, seria impróprio e pernicioso para eles usufruir dessa vivência (MENDONÇA, 2008, p. 67).

A espera pela extinção natural da escravidão evitaria que a sociedade entrasse em eminente "insurreição", bastando apenas "uma faísca" para eclodir, pois Alencar entendia que "no momento em que plainasse sobre o país uma lei de emancipação qualquer; toda casta sujeita se colocaria à sombra dela, para deduzir daí seu direito indisputável". Tal argumento certamente estava conectado com os instigantes debates em curso naquele contexto político, por conta da possível aprovação da Lei do Ventre Livre, combatida veementemente pelo poeta, que acreditava na revolta da geração liberta para retirar do cativeiro seus progenitores, ação supostamente motivada pelo “estímulo nobre do amor filial" (ALENCAR, 1867-1868, p. 41-42).

Erasmo propagava que as circunstâncias políticas em voga levariam a emancipação a tornar-se "um edito de miséria pelo abandono do trabalho, e de extermínio por causa da luta que excita entre as duas raças" (ALENCAR, 1867-1868, p. 44), em alusão à provável revolta que uma lei emancipacionista eventualmente causaria, inviabilizando um processo pacífico de transição.

Na condição de advogado e estudioso da legislação, José de Alencar enfatizava que a solução para essa problemática não passava pela elaboração de mais uma lei e, ao contrário do Imperador D. Pedro II, era totalmente desfavorável à intervenção do Estado nos debates políticos em torno da escravidão, por acreditar que a emancipação deveria 
acontecer por intermédio da mudança "nos costumes, que são a medula da sociedade" (ALENCAR, 1977, p. 197).

Como a escravidão era considerada uma "instituição" e estava arraigada no cotidiano do século XIX, uma lei não seria capaz de eliminá-la. Tal posicionamento situava Alencar como um defensor ferrenho da doutrina que justificava o descumprimento da legislação contra o tráfico de escravos pela via da "força dos costumes senhoriais". O chamado "direito costumeiro dos senhores ao trabalho escravo" (CHALHOUB, 2012a, p. 75-76) considerava essa legislação contrária à natureza daquela sociedade, desprovida de sustentação diante das práticas usuais. Erasmo tinha ciência da força contida em "tudo o que em matéria de moral se faz por hábito ou rotina" (PINTO, 1832, s.p.) e, ao afirmar que a mudança deveria ocorrer nos costumes, aludia a uma prática que remetia à persistência dos interesses senhoriais.

A transformação dessa prática costumeira era considerada um acontecimento natural fomentado pela razão social, que convenceria os abolicionistas da necessidade da escravidão findar seu tempo naturalmente. Entretanto, o literato reconhecia que nem todos acreditavam nos "instintos humanos" como responsáveis por um fim natural à escravidão e apoiavam o uso de medidas legislativas. Para contrapor essa opinião, alegava que "todo povo, toda família humana acaba, cedo ou tarde, por conquistar a liberdade", considerando qualquer proposição contrária como uma calúnia contra a humanidade (ALENCAR, 1867-1868, p. 29).

O entendimento de José de Alencar era fundamentalmente baseado na proposta que atribuía aos costumes a responsabilidade por viabilizar a emancipação e, para tanto, defendia que isso ainda não havia se concretizado no Brasil, devido à necessidade de manutenção desse "mau regime de trabalho". Citava convicto aquilo que denominava como "injustiça absoluta do seu domínio" entre os senhores de escravos, indicativo de seu reconhecimento da necessária e inicial transformação nos costumes. Por outro lado, enxergava a existência de um "espírito de tolerância e generosidade" capaz de transformar sutilmente a escravidão.

Defendia a ineficiência das leis contrárias ao tráfico (1831 e 1850), ao insistir que "todos os indivíduos novamente importados eram lançados à conta do tempo em que era lícita essa aquisição" (ALENCAR, 1867-1868, p. 42). Alertava ainda que a Lei do Ventre Livre poderia retroagir "ao cativeiro os nascimentos acontecidos já no período de liberdade" (ALENCAR, 1867-1868, p. 42). Ora, não se pode negar que a escravização ilegal de africanos se manteve a pleno vapor no Brasil, impulsionada por 
vias clandestinas e sustentada pela demanda de trabalhadores nas fazendas paulistas de café, mediante a conivência e corrupção de autoridades públicas, aliada ao apoio de setores variados da população.

Cumpre destacar a defesa do Partido Conservador em torno dos interesses de proprietários rurais ligados à manutenção da escravidão, fomentada tanto pelo tráfico quanto pela "reprodução natural positiva" dos cativos (SALLES, 2012, p. 9). Não era à toa que Alencar aconselhava a "meditação" para o encaminhamento da emancipação, tendo em vista a necessária "preparação moral e econômica do país" para o trabalho livre. Embora admitisse que perante a lei os escravizados eram considerados "coisas", insistia que "o costume, a razão pública, mais poderosa que todas as leis escritas" eram responsáveis pela elevação dos escravizados à "condição de homem, embora interdito e sujeito".

Ressaltava o direito de propriedade exercido por eles por meio da aquisição do pecúlio, da exploração das chamadas "pequenas indústrias" e do acesso ao matrimônio, "mais sagrado" contrato civil do país. Sua alegação era que a "opinião" mantém e consolida essas garantias, ainda que elas tenham se estabelecido fora da lei, novamente em posição contrária ao uso de medidas legislativas para a resolução de questões costumeiras. Em suma, na disputa entre as leis e os costumes, a prática do direito costumeiro prevaleceria e a despeito dos debates acalorados e das divergências de posicionamento, Alencar era favorável à extinção natural da escravidão para a libertação dos escravos, ao defender que a emancipação deveria acontecer por intermédio da mudança nos costumes.

Alegava que o "vínculo de família" era fundamental nas relações entre senhores e escravos e reafirmava sua convicção naquilo que chamava de "natural e não remota extinção da escravidão em nosso país" (ALENCAR, 1867-1868, p. 30-32). Esses argumentos também se mostraram evidentes nos discursos parlamentares de 1870, onde mencionava que a emancipação deveria passar pela "iniciativa individual, o bom senso do povo, que legisla melhor pela educação e pelos costumes do que podem legislar os representantes da Nação por meio de leis expressas" (ALENCAR, 1977, p. 187). Em sua concepção, a transformação dos costumes traria "efeitos salutares", ou seja, "adoçaria o cativeiro", transformando o "domínio do senhor" em uma "tutela benéfica" (ALENCAR, 1867-1868, p. 42).

Sua ênfase recaía na preservação do que considerava "boas relações" entre senhores e escravos, sob o argumento de que "todas as concessões que a civilização vai 
obtendo do coração do senhor limam a escravidão sem a desmoralizar". Acreditava que o liberto se tornaria um "criado", em resposta à "benevolência do senhor" (ALENCAR, 1867-1868, p. 43) e mostrava-se favorável à preservação da ordem social, posição desenvolvida no parlamento, próximo à aprovação da Lei do Ventre Livre.

Na condição de deputado, em discurso de 13 de julho de 1871, declarava que não apenas era favorável às classes proprietárias, como também um defensor "dessa raça infeliz que se quer sacrificar". Para tanto, referenciava as manumissões e a emancipação espontânea como um "admirável aspecto" do país, com a citação da estatística de 1869, que indicava 14000 alforrias somente no Rio de Janeiro. Diante dos números, previu que "em menos de 20 anos a escravidão estaria extinta", compreendendo como rápida a marcha da "revolução moral" (ALENCAR, 1871b, p. 101).

No emblemático ano de 1871, os debates emancipacionistas foram intensificados e, na sessão de 9 de maio de $1871^{5}$, Alencar posicionou-se contrário à viagem do Imperador para a Europa, noticiada desde o final da Guerra do Paraguai. Esse conflito foi considerado inoportuno e arriscado, em função da agitação do país perante a questão "melindrosa" e a eminência da possível aprovação da Lei do Ventre Livre, compreendida pelo autor como uma subversão da "sociedade até seus fundamentos". Seu ponto central de implicância contra a viagem imperial era a substituição de D. Pedro II por sua filha, diante da enorme possibilidade de libertação do ventre via legislação promulgada pela "augusta princesa imperial" (ALENCAR, 1871a, p. 15).

Apesar de ter elaborado extensa argumentação nas Cartas Sobre a Emancipação e nos discursos na Câmara versando sobre a ineficácia de tal medida legislativa, Alencar foi derrotado, pois cerca de 4 meses depois do discurso sobre a viagem imperial, o ventre foi libertado oficialmente pela Lei n. 2.040 (BRASIL, 1871), assinada em 28 de setembro de 1871 pela "Princesa Imperial Regente". No entanto, conforme já citado, seu debate no parlamento foi marcado por forte oposição, advinda não apenas de conservadores, mas também de liberais que, no exercício do cargo de deputado, consideravam-na insuficiente para concretizar as reformas. Dentre os 12 deputados da Província do Rio de Janeiro, 11 se posicionaram contra a lei (ALENCASTRO, 1997), dada sua ligação com as oligarquias e os latifundiários, com destaque para os cafeicultores associados ao Partido Conservador.

\footnotetext{
${ }^{5}$ José de Alencar organizou o discurso proferido em 9 de maio de 1871 sobre a viagem imperial no formato de livro, sendo publicado no mesmo ano pela Typ. Imp. E Const. De J. Villeneuve \& C.
} 
Os principais argumentos contrários eram pautados no entendimento de que essa lei feria o "direito de propriedade dos senhores", em função da libertação dos recémnascidos de mães escravas. Um de seus artigos previa a concessão de liberdade para as crianças acima de 8 anos, sob indenização do governo, bem como a possibilidade de permanecerem no trabalho servil até a idade de 21 anos. Além disso, a lei assegurava aos escravos o direito de comprar a alforria com a apresentação do pecúlio, situação considerada pelos legisladores como indenização pela liberdade.

Entre polêmicas e desacordos, a Lei do Ventre Livre contava com o apoio do próprio Imperador e, convém lembrar, tratava-se de uma questão que foi alvo de debates iniciados pelo próprio D. Pedro II, após o prolongamento da Guerra do Paraguai (18641870). Em sua Fala do Trono, o monarca afirmou que esse assunto "não pode deixar de merecer oportunamente a vossa consideração", desde que a "primeira indústria" (D. PEDRO II, 1889, p. 627) fosse preservada, sem prejuízos à economia agrícola brasileira. Para tanto, chamava a atenção dos deputados quanto à importância da imigração que, desde a aprovação da Lei de Terras (1850), era uma temática recorrente nos debates.

Seu enunciado era a regularização da questão fundiária, no entanto, foi utilizada pelo governo imperial como dispositivo legal para estimular a "venda de terras públicas para obter os recursos necessários à implantação de políticas para atrair colonos europeus" (CHALHOUB, 2012b, p. 38), direcionados à ocupação territorial e à formação de colônias. Desse modo, os imigrantes se tornariam pequenos proprietários e substituiriam gradativamente a mão de obra africana no país.

A vinda de imigrantes europeus ao Brasil também estava aportada nos debates raciais, que propuseram como fator de progresso o aumento da população branca sobre a negra. Os dados estatísticos indicados pelo Almanak Laemmert (1851) demonstravam que, somente a Corte, reuniu 110 mil escravos, em uma população de 226 mil habitantes. O objetivo dessa medida era ampliar a população branca para alcançar a suposta civilização, por meio do branqueamento do povo brasileiro, com prognósticos e previsões acerca do tempo que levaria para o negro desaparecer do país (FERREIRA, 1998, p. 113).

Tais concepções contribuíram para que a escravidão se tornasse sinônimo de atraso e as políticas imperiais fossem reforçadas no sentido de envidar esforços para alterar essa configuração. Segundo José de Alencar, D. Pedro II cedeu às pressões externas e foi levado a fechar os olhos para a realidade brasileira e atender às "paixões 
estrangeiras", ao declarar ao Imperador: "Correstes após. Mas deslumbrado pela visão espetacular, abandonastes a luz pura, límpida e serena da verdadeira glória, para seguir o falaz clarão. Proteger, ainda com sacrifício da pátria, os interesses de outros povos" (ALENCAR, 1867-1868, p. 9).

A temática da imigração estrangeira também foi abordada na terceira carta sobre a emancipação, quando Erasmo iniciou uma discussão acerca do que denominava "repulsão e amálgama" das raças humanas, destacando a lentidão do processo de coesão e propondo que a escravidão fosse resolvida mediante a "absorção de uma raça pela outra". Caso a fusão entre ambas fosse viabilizada, a escravidão cairia "decrépita e exânime de si mesma, sem arranco nem convulsão, como o ancião consumido pela longevidade que se despede da existência adormecendo" (ALENCAR, 1867-1868, p. 21-22). Nas correspondências sobre emancipação enviadas por Erasmo ao Imperador, José de Alencar apontava a vinda de estrangeiros ao Brasil como possível solução para o término do sistema escravocrata, sustentado no ideal de amálgama de raças.

Considerava a emigração europeia "a grande artéria que despeja novo sangue vigoroso no organismo do país enervado pelo trabalho escravo". Todavia, alegava que se a Europa não ingerisse os gêneros coloniais em tamanha quantidade, a escravidão já teria cessado na América, atribuindo ao continente europeu a responsabilidade pela manutenção do tráfico, que ainda vigorava em território nacional ${ }^{6}$. Sua ênfase consistia ainda na crítica em torno da ineficácia da política imperial, ao citar o parco interesse europeu no envio de contingente populacional para efetivar a emigração no país. Alegava que se o subsídio anual do período de 1852 a 1867 tivesse sido de 60 mil europeus, "a escravidão teria cessado neste país” (ALENCAR, 1867-1868, p. 35-37), sem lei abolicionista.

Não era incomum a divergência de opiniões acerca da articulação entre imigração e escravidão, com uma infinidade de artigos publicados pela imprensa diária, tanto pela via de editoriais quanto "a pedido" de autores diversos, remetidos por carta aos próprios periódicos. Exemplo disso recai sobre o texto assinado por Muitos Fazendeiros, cujo teor indicava: "dolorosas experiências, tristes decepções têm demonstrado que o imigrante europeu, agrupando-se nas cidades, explora o comércio e a indústria, tornando-se entre nós, consumidor e não produtor” (MUITOS..., 1870, p. 3),

\footnotetext{
${ }^{6}$ Para maiores detalhes, sugiro a leitura de bibliografias fundamentais e clássicas para a discussão acerca do racismo no Brasil do séc. XIX: ANDREWS, 1998; SCHWARCZ, 1993; SKIDMORE, 2012.
} 
em referência à defesa da escravidão como solução para a continuidade de seus projetos econômicos de expansão e contrários à substituição da mão de obra escrava.

O debate era tão intenso que repercutiu com rigor na imprensa do Rio de Janeiro e São Paulo, no período entre agosto de 1867 a dezembro de 1868. Em geral, os artigos apontavam Alencar como defensor da escravidão, a exemplo de um texto publicado no Jornal do Commercio, escrito por alguém que portava o pseudônimo de Erasmo e declarava: "é realmente necessária muita coragem para neste século sustentar que o homem é capital do homem, e que a escravidão é uma instituição tão respeitável como a colonização" (ERASMO, 1867, p. 1). No jornal Cabrião, havia um reconhecimento de Erasmo como um indivíduo de grande "erudição", todavia, não aceitavam a sua "enfatuada, mas carunchosa opinião sobre a emancipação dos escravos" (CABRIÃO, 1867, p. 347).

Apenas um artigo, assinado por "um discípulo", publicado no Jornal do Commercio de 7 de agosto, declarava Erasmo como incompreendido em suas intenções e indicava que aos seus críticos faltava "o tempo ou a paciência para ler com atenção", acusando-os de julgamento por aquilo que denominou de "algumas frases truncadas" (UM DISCÍPULO, 1867, p. 2). Essa defesa pode ser conectada a um discurso de Alencar na Câmara, em 1870, quando destacou que há quinze anos se "esforçava, no campo que se abria então à minha atividade na literatura e na Imprensa, em banir essa instituição" (ALENCAR, 1977, p. 197).

Certamente, Alencar se referia ao período posterior a 1855, quando publicou peças de teatro com o tema da escravidão, como $O$ Demônio Familiar e Mãe, consideradas por Machado de Assis um "protesto" contra a escravidão e um discurso que inspiraria "ao povo o horror pela instituição do cativeiro" (ASSIS, 1994). Alencar alegava que o fim da escravidão era uma aspiração candente de todos os brasileiros, cujo objetivo era deixar de ser no "mundo civilizado a exceção triste" (ALENCAR, 1977, p. 186-187).

Em consonância com as Cartas de Erasmo, seus discursos na Câmara desfavoreciam o encaminhamento da reforma por medidas legislativas, em favor da mudança dos costumes e da opinião pública, considerada por ele a "verdadeira soberana" na direção das reformas (ALENCAR, 1977, p. 186-187). Nas cartas sobre a emancipação, Alencar defendia a subordinação, sustentada pela "proteção dos senhores e gratidão dos dependentes", associada a uma emancipação voluntária e definida pelo senhor (CHALHOUB, 2003, p. 200). Portanto, não era contrário ao ideal de concessão 
de liberdade, desde que o processo fosse intermediado pela vontade dos senhores, em defesa da continuidade do mundo senhorial, mediante a manutenção do domínio dos senhores e a preservação das relações de interdependência entre as partes.

Além disso, reconhecia que o partido Conservador não era "abolicionista na atualidade", além de argumentar jamais ter pretendido que o partido adotasse a posição de "escravagista", muito menos aceitasse a "escravidão como uma instituição firmada no direito, na moral que deva ser mantida e respeitada". Ao afirmar que todos “desejamos ardentemente ver desaparecer do País essa instituição" (ALENCAR, 1977, p. 186), referia-se tanto aos conservadores quanto aos liberais, embora admitisse a predominância dos primeiros em torno da defesa da manutenção do sistema escravista.

Contudo, isso não quer dizer que todos os conservadores fossem escravocratas e todos os liberais, como consequência, abolicionistas, pois entre a ala liberal havia quem defendesse a continuidade do tráfico escravo, caso de Joaquim Breves, cuja leitura do liberalismo era pautada na "liberdade de comercializar, mesmo que as mercadorias fossem indivíduos juridicamente livres” (PESSOA, 2011, p. 40) no Brasil.

Entre polêmicas e declarações contrárias à emancipação como "questão máxima do dia” (ALENCAR, 1867-1868, p. 12), a argumentação elaborada nas Cartas de Erasmo era veementemente contrária às medidas legislativas para o encaminhamento dessa querela política, conforme já demonstrado. Com uma defesa explícita da prescrição natural da escravidão, a narrativa transparecia a resistência dos escravocratas à mudança, ideal fortemente arraigado ao processo de construção do Estado nacional independente e articulado à manutenção da propriedade escrava ilegal, originária do contrabando maciço de africanos escravizados, elementos incompatíveis e fatores de detração da transformação nas práticas sociais do Brasil oitocentista.

Nas Cartas de Erasmo defendeu a caducidade natural da escravidão e a emancipação pautada na alteração dos costumes. Sua justificativa indicava a existência de instituições mais bárbaras do que a escravidão e o reconhecimento de que embora fosse uma forma rude do direito, também representava progresso e instrumento de civilização. O literato mostrava-se contrário à política imperial, que se utilizava da legislação para, gradativamente, chegar à emancipação dos escravos, ao apresentar elementos que expressavam a ineficácia dessa estratégia política.

Conclui-se que a linha mestre de argumentação de José de Alencar nas Cartas de Erasmo se sustentava no cultivo das relações de dependência entre senhores e escravos, operadas por meio da mudança nos costumes e na índole da sociedade, em um processo 
que "adoçava" o cativeiro, transformado em servidão até chegar à ausência de amparo dos escravocratas, que resultaria na redução do controle dos senhores em uma tutela benéfica, preservando os termos da continuidade do domínio senhorial, com o mínimo possível de ruptura.

Em complemento, Alencar defendia a imigração como uma artéria que despejaria sangue novo ao país, cuja força se esvaiu no trabalho escravo, com enfática acusação à Europa como continente responsável pela manutenção do tráfico que, ao arrepio da lei, ainda vigorava em território nacional. Além disso, atribuía à Europa a responsabilidade de manutenção da escravidão no Brasil, ao referenciar o que denominava de "pouco interesse" europeu no envio de contingente populacional para efetivar a emigração no país, sob a alegação de que se o subsídio anual do período de 1852 a 1867 tivesse sido de 60 mil europeus, o resultado seria o término da escravidão no Brasil, sem lei abolicionista.

\section{Referências}

\section{Fontes}

\section{José de Alencar}

ALENCAR, José de. A Viagem Imperial (Câmara dos Deputados - Sessão em 9 de maio de 1971). Rio de Janeiro: Typ. Imp. E Const. De J. Villeneuve \& C., 1871a.

. Ao Imperador: cartas de Erasmo. Rio de Janeiro: Typ. de Mello, 1865.

1867-1868.

Ao Imperador: novas cartas políticas. Rio de Janeiro: Typ. de Pinheiro \& Cia, Ao Marquez de Olinda. Rio de Janeiro: Typ. de Pinheiro, 1866a.

Ao Povo: cartas políticas de Erasmo. Rio de Janeiro: Typ. De Pinheiro \& Comp., 1866b.

- Ao Visconde de Itaboraí: carta de Erasmo sobre a crise financeira. Rio de Janeiro: Typ. de Pinheiro Comp., 1866c.

- Carta ao Visconde de Itaboraí. In: ALENCAR, José de; MENEZES, Raimundo de (orgs). Cartas e documentos de José de Alencar. 2. ed. São Paulo: Hucitec, 1977.

Como e porque sou romancista. Rio de Janeiro: Typ. de G. Leuzinger \& Filhos, 1893. 
ALENCAR, José de. Como e porque sou romancista. Rio de Janeiro: Typ. de G. Leuzinger \& Filhos, 1893.

. Discursos parlamentares de José de Alencar: Deputado-geral pela província do Ceará (1861 a 1877). Brasília: Câmara dos Deputados, 1977.

Discursos Proferidos na Sessão de 1871 na Câmara dos Deputados. Rio de Janeiro: Typographia Perseverança, $1871 b$.

\section{Imprensa e legislação}

ASSIS, Machado de. Obra Completa de Machado de Assis. Rio de Janeiro: Nova Aguilar, vol. III, $1994 . \quad$ Disponível em: <http://machado.mec.gov.br/images/stories/pdf/critica/mact15.pdf $>$. Acesso em 15/02/2016.

CABRIÃO. Cabrião. São Paulo, 11 ago. 1867, p. 347.

D. PEDRO II. Fallas do throno: desde o ano de 1823 até o ano de 1889. Rio de Janeiro: Imprensa Nacional, 1889.

ERASMO. Jornal do Commercio. Rio de Janeiro, 6 ago. 1867, p. 1.

BRASIL. Lei $\mathrm{n}^{\circ} 2.040$ de 28 de setembro de 1871. Lei do Ventre Livre. [Manuscrito]. Disponível em: http://www2.senado.leg.br/bdsf/item/id/496715. Acesso em 13/12/2016.

MUITOS FAZENDEIROS. Emancipação (Carta ao Exm. Sr. Visconde de Barbacena). Jornal do Commercio. Rio de Janeiro, 05 jun. 1870, p. 3.

PINTO, Luiz Maria da Silva. Diccionario da Lingua Brasileira. Ouro Preto, Typographia de Silva, 1832.

S. PAULO. Fazendeiros da Província de. Emancipação. Jornal do Commercio, Rio de Janeiro, 28 maio 1870, p. 2.

UM DISCÍPULO. Cartas de Erasmo. Jornal do Commercio, Rio de Janeiro, 7 ago. 1867, p. 2.

\section{Bibliografia}

ALENCASTRO, Luiz Felipe de. Vida privada e ordem privada no Império. In: ALENCASTRO, Luiz Felipe de (org). História da vida privada no Brasil: Império. São Paulo: Companhia das Letras, 1997.

ANDREWS, George Reid. Negros e brancos em São Paulo (1888-1988). Bauru: EDUSC, 1998.

AZEVEDO, Celia Maria Marinho de. Abolicionismo: Estados Unidos e Brasil, uma história comparada (século XIX). São Paulo: Annablume, 2003. 
CARVALHO, José Murilo de. A construção da ordem: a elite política imperial. Teatro de sombras: a política imperial. Rio de Janeiro: Civilização Brasileira, 2008.

ALENCAR, José de. Cartas de Erasmo. Rio de Janeiro: ABL, 2009, p. VII-XXVIII.

CHALHOUB, Sidney. Machado de Assis: historiador. São Paulo: Companhia das Letras, 2003.

A Força da Escravidão: ilegalidade e costume no Brasil oitocentista. São Paulo: Companhia das Letras, 2012a.

População e Sociedade. In: CARVALHO, José Murilo de (org). A Construção Nacional: 1830-1889. Rio de Janeiro: Objetiva; Madrid: Fundación Mapfre, 2012b.

ERASMO de Roterdã. Conselhos aos Governantes. Brasília: Senado Federal, 1998.

FERREIRA, Cristina. Cidadania e identidade na sociedade teuto-brasileira: José Deeke e os embates culturais interétnicos no Vale do Itajaí. Dissertação (Mestrado em História), Universidade Federal de Santa Catarina, Florianópolis, 1998.

.; LENZ, Thiago. Duas narrativas para o lugar dos indígenas nas origens da nação: a história ficcional de Magalhães e Alencar. Almanack, Guarulhos, n. 23, p. 202238, dez. 2019.

GOMES, Ângela de Castro. Rascunhos de história imediata: de monarquistas e republicanos em um triângulo de cartas. In: GOMES, Ângela de Castro; SCHIMIDT, Benito Bisso (orgs). Memórias e narrativas (auto)biográficas. Rio de Janeiro: Editora FGV, 2009.

MAMIGONIAN, Beatriz Gallotti. A proibição do tráfico atlântico e a manutenção da escravidão. In: GRINBERG, Keila; SALLES, Ricardo (org.). O Brasil Imperial: Volume I. 3. ed. Rio de Janeiro: Civilização Brasileira, 2014.

MENDONÇA, Joseli Maria Nunes. Entre a mão e os anéis: a Lei dos Sexagenários e os caminhos da abolição do Brasil. Campinas: Ed. Unicamp, 2008.

MENEZES, Raimundo de. José de Alencar: literato e político. São Paulo: Martins, 1965.

MOLINA, Matias. História dos Jornais no Brasil: Da era colonial à Regência (15001840). São Paulo: Companhia das Letras, 2015.

PARRON, Tâmis. Introdução. In: PARRON, Tâmis (org); ALENCAR, José de. Cartas a favor da escravidão. São Paulo: Hedra, 2008.

PESSOA, Thiago Campos. Outras dimensões do Infame Comércio: conservadores, liberais e o Estado Imperial no contexto da ilegalização do tráfico de africanos. In: ABREU, Martha; PEREIRA, Matheus Serva (orgs). Caminhos da Liberdade: histórias da abolição e do pós-abolição no Brasil. Niterói: PPGHistória UFF, 2011. 
RODRIGUES, Antonio Edmilson Martins. José de Alencar: o poeta armado do século XIX. Rio de Janeiro: Editora FGV, 2001.

SALLES, Ricardo. O Império do Brasil no contexto do século XIX. Escravidão nacional, classe senhorial e intelectuais na formação do Estado. Almanack, Guarulhos, n. 4 , p. $5-45,2012$.

SCHWARCZ, Lilia Moritz. O espetáculo das raças: cientistas, instituições e questão racial no Brasil 1870-1930. São Paulo: Companhia das Letras, 1993.

.; GOMES, Flávio dos Santos (orgs). Dicionário da escravidão e liberdade. São Paulo: Companhia das Letras, 2018.

SKIDMORE. Thomas. Preto no branco: raça e nacionalidade no pensamento brasileiro. São Paulo: Companhia das Letras, 2012.

VIANA, Maria Rita Drumond. "Não se pode lutar uma batalha com sussurros": a prática epistolar de W. B. Yeats e sua correspondência para periódicos no século XIX. Tese (Doutorado em Estudos Linguísticos e Literários em Inglês), Universidade de São Paulo, São Paulo, 2015.

Artigo recebido em 27 de maio de 2021. Aceito em 15 de julho de 2021. 